\title{
Quality Assessment of Ground Water in and Around Erumapalayam, Municipal Solid Waste Dumpsite Area in Salem
}

\author{
Narmatha. M \\ Department of Civil Engineering, Pavai College Of Technology, Namakkal
}

\begin{abstract}
The Municipal Solid Waste generated in Salem was estimated 335 Million tons per day which is being dumped and accumulated in Erumapalayam dumping yard for the past four decades. Due to the poor scientific management of landfill, the ground water may be contaminated through the leach ate. This study has extensively analyzed the impacts on ground water caused by the non-scientific solid waste management and disposal methods. In order to assess the present status of ground water quality, a total of 25 water samples were collected from all the directions in a radius of $1000 \mathrm{~m}$ from the dumping yard. The collected water samples were analyzed for parameters of Total Dissolved Solids (TDS), Total Alkalinity (TA), Total hardness, calcium, magnesium, sulphate, Nitrate, chloride and fluoride. Also, Water Quality Indices were determined for all the water samples. The study reveals that the concentration of above parameters exceeds the permissible value of BIS (Bureau of Indian standards) and WHO (World Health Organization) standards in almost all the samples. WQI (Water Quality Indices) reveals that water quality rating of samples falls in two categories namely poor and very poor. Hence, the ground water around the dumping yard is found to be non-potable.
\end{abstract}

Keywords: Total hardness, Total Alkalinity, decades, Nitrate.

\section{Introduction}

Water is an indispensable natural resource on earth. Safe drinking water is the primary need of every human being. Fresh water has become a scarce commodity due to over exploitation and pollution of water. Groundwater is the major source of drinking water in both urban and rural areas. Groundwater is the most important source of water supply for drinking, irrigation and industrial purposes. Better quality of water is described by its physical, chemical and biological characteristics. Due to the increased human population, industrialization, use of fertilizers in agriculture and man-made activities the water gets polluted. It is therefore necessary that, the quality of drinking water should be checked at regular time interval because due to the use of contaminated drinking water, human population suffers from a variety of water borne diseases.

\section{Municipal Solid Waste}

Municipal Solid Waste (MSW) is generally a combination of household and commercial refuse which is generated from the living community. Among the multitude of the environmental problem existing in the urbanizing cities of developing countries, MSW management and its impact on groundwater quality have become the most prominent in the recent years. There has been a significant increase in the generation of MSW (Municipal Solid Wastes) in India over the last few decades. This is largely a result of rapid population growth in the country. The daily per capita generation of municipal solid waste in India ranges from about $100 \mathrm{~g}$ in small towns to $500 \mathrm{~g}$ in large towns. The solid waste generated in Indian cities has increased 6 million tons in 1947 to 48 million tons in 1997 and is expected to increase to 300million tones per annum by 2047 (CPCB, 2000). The characteristics of MSW collected from any area depends on a number of factors such as food habits, cultural traditions of inhabitants, lifestyles, climate, etc. At present most of the MSW in the country is disposed off unscientifically (i.e.) lack of 'sanitary landfill'. The Plastic content of the municipal waste is picked up by the rag pickers for recycling either at primary collection centers or at dumpsites. Plastic are recycled mostly in factories, which do not have adequate technologies to process them in a safe manner. This exposes the workers to toxic fumes and un hygienic conditions. Moreover, since the rag picking sector is not organized, not all the recyclables, particularly plastic bags, get picked up and are found littered everywhere, reaching the drains and water bodies ultimately and choking them.

\section{Introduction}

\section{Literature Review:}

In many of the third world countries like India, uncontrolled land disposal of municipal solid waste is a common practice even today. The unregulated waste dumps and landfills cause a number of environmental and human health hazards, the most significant of them being the groundwater contamination. Growing concerns about public health and degrading groundwater quality due to the polluting waste dumps and landfills call for 
taking appropriate remedial action or control measures at these sites. However, due to financial constraints, required remedial actions cannot be taken at all sites. Thus the assessment of their relative hazard potential could help priorities the different sites for Rehabilitation. Since, the leach ate being the longest lasting emission of landfills (Kylefors 2003), the leachate contamination of groundwater is the most significant of all landfill hazards. Therefore, the groundwater contamination hazard potential of different waste sites can be considered as an appropriate basis for their prioritization. Numerous approaches ranging from deterministic water balance analyses and stochastic failure simulations to relative hazard ranking methods to evaluate landfill hazard have been developed. Each one of these has some merits and demerits.

\section{Complete Description}

The system presented here evaluates the relative hazard of a landfill in comparison with the other landfills. Various system parameters describing the source, pathway and receptor were identified based on literature and the expert opinions. For selection of the parameters and assigning them relative importance weights, a questionnaire indicating the parameters identified based on literature was sent to an expert panel consisting of academics, field engineers, consultants, and regulators drawn from various parts of the world. The panelists were requested to add any other parameter(s) of relevance to the groundwater contamination potential of municipal waste sites, and then rate all parameters including the ones identified from literature on a scale of 0 -10. A rating of ' 0 ' indicated that parameter is not important all, Hence should not be included, whereas rating of 10 was to be assigned to the most important parameter. Based on the input of the panelists, the final input parameters of the model were decided. The relative importance weights of various input parameters were decided using the Delphi technique (Dalkey, 1968).

\section{Classification of Water Pollution}

Water pollution can be classified in to four categories, viz., physical, chemical, biological and physiological pollution of water.

\section{Physical Bpollution Of Water}

It brings about changes in water with regards to its colour, odour, density, taste, turbidity and thermal properties. They may be interrupted and brought about in various ways and means of testing. Physical pollution is the one which is being noted first for any kind of water which is contaminated. It can be seen through naked eyes and tasted within certain limits.

\section{Chemical Pollution Of Water}

The chemical pollution water causes in acidity, alkalinity or $\mathrm{pH}$ and dissolved oxygen. It may be caused either by organic pollutants or inorganic pollutants or by both. The organic pollutants can be biodegradable or non-biodegradable.

Biodegradable organic pollutants which degrade easily include proteins from domestic sewage, waste from ceramics, canneries \& slaughter houses sugar starch from sewage textile mills etc, Non biodegradable organic pollutants which persist in the aquatic system for a long time (ex) patricides, fungicides, herbicides, insecticides, toxides etc.

Biological Pollution Of Water-Bacteriological pollution of water in due to the presence of pathogenic bacteria, certain fungi, pathogenic protozoa, viruses, parasite worms etc. The important sources of this type are domestic sewages industrial wastes. Solid excreta from human bodies \& decomposable organic matter of sewage are the best medium for the development of bacteria in water.

Bacteria pollution in water is caused by the excretory products of warm blooded mammals man, wild \& domestic animals). Waste waters are rich in bacteria algace protozoa worms and other organisms. The greater amount of nutrients in water, the faster the biological contamination.

\section{Description Of Study Area:}

\section{Material And Methodology}

Erumapalayam is a Village in Salem Taluk, Salem District, Tamil Nadu State . Erumapalayam is located $5.9 \mathrm{~km}$ distance from its Taluk Main Town Salem. Erumapalayam is $4.5 \mathrm{~km}$ far from its District Main City Salem . It is $276 \mathrm{~km}$ far from its State Main City Chennai . More than 2.5 lakh MT of solid waste was dumped in the 14-acre yard at Erumapalayam for the past 50 years as the mounting garbage is about 18 feet high. Around 350 MT solid waste, collected from all the 60 wards, were earlier taken to the plant for processing on the city outskirts. 


\section{Sample Collection:}

The sample bottles were rinsed two or three times with the water being collected before filling. The container was filled without air space, including the handle of the container.

The container was closed with the inner cap along with a polyethene sheet $(10 \mathrm{~cm} \times 10 \mathrm{~cm})$. The outer cap also covered with a polyethene sheet.

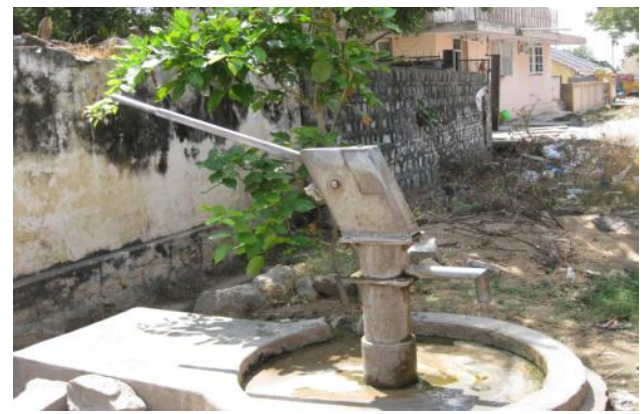

Fig1: Water sample collected area

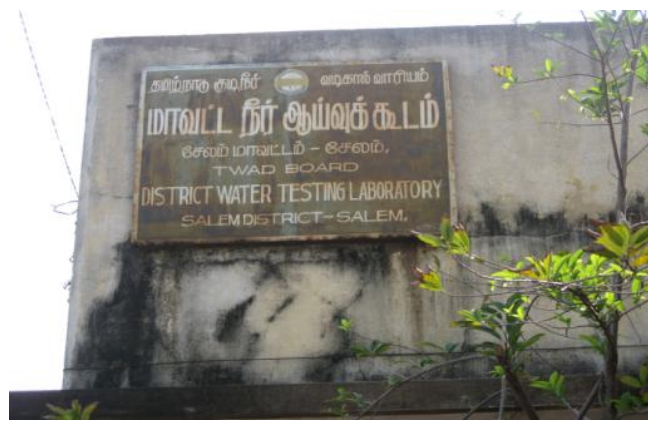

Fig 2: District Water Testing Laboratory

Analysis Of Water Quality Parameters:

The analysis and the testing were being carried out under the guidance of the member from TWAD board in

Testing

Laboratory

\begin{tabular}{|c|c|c|c|}
\hline Sample.No & Date & Loacation & Reason\& Result \\
\hline 01 & \multirow{6}{*}{21.03 .13} & Kichippalayam Street 1 & $\begin{array}{c}\text { Non Potable } \\
\text { Appearance } \\
\text { Odour } \\
\text { Turbidity } \\
\text { Total Dissolved Solids } \\
\text { Iron }\end{array}$ \\
\hline 02 & & Kichippalayam Street 2 & $\begin{array}{c}\text { Non Potable } \\
\text { Appearance } \\
\text { Turbidity } \\
\text { Total hardness } \\
\text { Iron } \\
\text { Phosphate } \\
\text { Fluoride } \\
\text { Total dissolved solids }\end{array}$ \\
\hline 03 & & Ammapet Street 1 & Potable \\
\hline 04 & & Ammapet Street 2 & Potable \\
\hline 05 & & Ponnammapet Main road & $\begin{array}{l}\text { Non Potable } \\
\text { Appearance } \\
\text { Odour } \\
\text { Turbidity } \\
\text { Iron } \\
\text { Phosphate } \\
\text { Ammonia }\end{array}$ \\
\hline 06 & & Ponnamapet Gate & $\begin{array}{l}\text { Non potable } \\
\text { Apperence } \\
\text { Odour } \\
\text { Ammonia } \\
\text { Fluoride } \\
\text { Phosphate } \\
\text { BOD }\end{array}$ \\
\hline
\end{tabular}


Quality Assessment Of Ground Water In And Around Erumapalayam, Municipal Solid .....

\begin{tabular}{|c|c|c|}
\hline & & COD \\
\hline 07 & $\begin{array}{c}\text { Kalarampatty Nehru } \\
\text { Street }\end{array}$ & $\begin{array}{c}\text { Non potable } \\
\text { Appearance } \\
\text { Odour } \\
\text { Turbidity } \\
\text { Total dissolved solids } \\
\text { Total hardness } \\
\text { Ammonia } \\
\text { Fluoride } \\
\text { Phosphate } \\
\text { Iron }\end{array}$ \\
\hline 08 & Naval Nagar & $\begin{array}{c}\text { Non-Potable } \\
\text { Appearance } \\
\text { Odour } \\
\text { Ammonia } \\
\text { Phosphate } \\
\text { Iron }\end{array}$ \\
\hline 09 & $\begin{array}{c}\text { E.B Office } \\
\text { Seelanaickenpatty }\end{array}$ & $\begin{array}{c}\text { Non Potable } \\
\text { Appearence } \\
\text { Total Dissolved Solids } \\
\text { Total Hardness } \\
\text { Odour } \\
\text { Fluoride } \\
\text { Iron } \\
\text { Phosphate }\end{array}$ \\
\hline 10 & $\begin{array}{c}\text { Seelanaickenpatty } \\
\text { byepass }\end{array}$ & $\begin{array}{c}\text { Non Potable } \\
\text { Total Hardness } \\
\text { Total Alkalinity } \\
\text { Calcium } \\
\text { Sodium } \\
\text { Iron } \\
\text { Potassium } \\
\text { BOD } \\
\text { COD }\end{array}$ \\
\hline 11 & Sanyasigundu street 1 & $\begin{array}{c}\text { Non potable } \\
\text { Appearance } \\
\text { Iron } \\
\text { Phosphate } \\
\text { Free Ammonia, } \\
\text { Sulphate } \\
\text { Odour, } \\
\text { Turbidity }\end{array}$ \\
\hline 12 & Sanyasigundu street 2 & $\begin{array}{c}\text { Non Potable } \\
\text { Turbidity, } \\
\text { Odour } \\
\text { Iron } \\
\text { phosphate, } \\
\text { Sulphate, } \\
\text { Free Ammonia } \\
\text { BOD } \\
\text { COD }\end{array}$ \\
\hline 13 & Dadagapatty Gate & Potable \\
\hline 14 & Devendrapuram & Potable \\
\hline 15 & Parasakthi Nagar & Potable \\
\hline 16 & Shivaji Nagar & $\begin{array}{c}\text { Non Potable } \\
\text { Phosphate } \\
\text { Free Ammonia } \\
\text { Potassium } \\
\text { Magnesium }\end{array}$ \\
\hline 17 & Annathanapatty & Potable \\
\hline 18 & Karungalpatty & $\begin{array}{c}\text { Non Potable } \\
\text { Total hardness } \\
\text { Iron } \\
\text { Flouride } \\
\text { Sulphate } \\
\text { BOD } \\
\text { COD } \\
\end{array}$ \\
\hline
\end{tabular}


Quality Assessment Of Ground Water In And Around Erumapalayam, Municipal Solid .....

\begin{tabular}{|c|c|c|}
\hline 19 & Indra Nagar & $\begin{array}{c}\text { Non Potable } \\
\text { Turbidity } \\
\text { Potassium } \\
\text { Sulphate } \\
\text { Free Ammonia } \\
\text { Total solids }\end{array}$ \\
\hline 20 & Joy Nagar & Potable \\
\hline 21 & Boyer theru & $\begin{array}{c}\text { Non Potable } \\
\text { Appearence } \\
\text { Turbidity } \\
\text { Total dissolved solids } \\
\text { Nitrite } \\
\text { BOD } \\
\text { COD }\end{array}$ \\
\hline 22 & Valluvar Nagar & $\begin{array}{l}\text { Non Potable } \\
\text { Appearence } \\
\text { Ammonia } \\
\text { BOD } \\
\text { COD } \\
\text { Sodium }\end{array}$ \\
\hline 23 & Varkaran kuttai & $\begin{array}{c}\text { Non Potable } \\
\text { Total Alkalinity } \\
\text { Sodium } \\
\text { Potassium } \\
\text { BOD } \\
\text { COD }\end{array}$ \\
\hline 24 & Nallagounder kadu & $\begin{array}{c}\text { Non Potable } \\
\text { Turbidity } \\
\text { Phosphate } \\
\text { Iron } \\
\text { BOD } \\
\text { COD }\end{array}$ \\
\hline 25 & Devendrapuram $3^{\text {rd }}$ street & Potable Water \\
\hline
\end{tabular}

\section{Summary And Conclusion:}

The result interpretation brings out the most of the water sample contains mild to high iron concentration and mild to high fluoride and potassium concentration. Most of the samples contain high total dissolved solids and alkalinity when compared to the Indian standard of drinking water. When related to other terms concentration of BOD and COD is mild in all the regions. Potassium and total hardness are the one which are notably in high ranges in all the places of sample collection. With the comparison of standard drinking water it interprets that most of the area contains water which is not satisfactorily good it causes many health hazards. Conclusion- On the basis of the above discussion, it may be concluded that the underground drinking water at almost all the collected sites at Erumapalayam landfills dumpsite area was highly polluted in comparison with the Drinking Water Standards. In few sites, it was moderately polluted in the catchments study area. The drinking water is polluted with reference to almost all the water quality physicochemical parameters studied. Therefore, the use of such bore well water should be discouraged. People dependent on this water are often prone to health hazards due to polluted drinking water. Therefore, some effective measures are urgently required to enhance the drinking water quality.

\section{Reference}

[1]. "ISI (1991) Indian standard Drinking Water Specifications, New Delhi, 5, 16".

[2]. " "Laboratory Manual on Water Analysis, National Environmental Engineering Research Institute, Nagpur"

[3]. "WHO (2004) International standards of drinking water. World Health organization, Geneva. pp:55-79".

[4]. “Adelekan B A, International Journal of Water Resources and Environmental Engineering, 2010, 2 (6): 137-147”.

[5]. "Camp, T.R and R.L.Meserve (1974), Water and its impurities, $2^{\text {nd }}$ ed., Dowden, Hutchinson \& Ross, Stroudsburg, P.A"

[6]. "Quality Assessment of ground water in pallavaram municipal solid dumpsite area nearer to Chennai, Tamil Nadu"

[7]. "Safe Drinking Water Foundation (SDWF)"

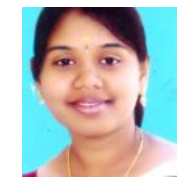

Ms.M.Narmatha completed her Diploma in Civil Engineering during 2002 at Kongu Polytechnic College, She completed her B.E degree in Civil Engineering during 2005 at K.S.R.College of Engineering. She completed her Masters in M.E Structural Engineering during 2010 at M.P.N.M.J Engineering college. She has 4 years of teaching experience. 